\title{
From Constitutional to Civic Patriotism
}

\author{
CÉCILE LABORDE*
}

Constitutional patriotism is an influential attempt to reconcile the conflicting imperatives of political legitimacy and cultural inclusiveness. However, it underestimates the role of particularist political cultures in grounding universalistic principles of democracy and justice. Civic patriotism, by contrast, emphasizes the motivational prerequisites of democratic governance, stresses the need to preserve existing 'co-operative ventures' such as nation-states, and demands that existing political cultures be democratically scrutinized and re-shaped in an inclusive direction. It promotes a mainly political identity, whose political content makes it compatible with a variety of practices and beliefs, but whose thin particularistic form justifies citizens' commitment to specific institutions. This commitment is not so unconditional as to justify blind loyalty to one's own institutions, nor is it so absolute as to rule out certain forms of cosmopolitan citizenship.

While numerous attempts have recently been made to reconcile liberal universalism with various forms of cultural membership, it has been an implicit assumption in the literature that nationalism and multiculturalism are doomed to remain strange bedfellows. It is easy to see why. Prima facie, one would expect that nationalists would be even less accommodating than universalists towards multicultural politics. While universalists typically insist on the culture-blind neutrality of the public sphere, and therefore deny public expression to all expressions of cultural identities, nationalists can be said to advocate the public promotion of one identity, national identity, at the expense of other group identities, which will, therefore, be indirectly discriminated against. By using public institutions to foster a particular culture, nationalism may conflict with the principle of equal citizenship, and is likely to be intolerant of minority cultures. As a result, liberal theories of citizenship have generally tended to regard nationalist claims with the utmost suspicion.

At the same time, however, there is a growing sense that citizens' attachment to their national institutions - what I call here patriotism - can be instrumental in fostering the virtues essential to the legitimacy and stability of liberal democracy. Is it possible to reconcile the conflicting imperatives of respect for cultural diversity and sustained democratic legitimacy? In Europe, an influential

* European Studies, King's College, London. Earlier versions of this article were presented to the UK Political Studies Association Annual Conference (Keele, April 1999), the LSE Seminar in International Political Theory (January 2000), and the Nuffield Political Theory Workshop in Oxford (February 2000). Special thanks are due to their participants, and to Catherine Audard, Dario Castiglione, Cécile Fabre, Peter Hallward, John Horton, Catriona McKinnon, Andrew Mason, David Miller, Jan Müller and Alan Patten for their helpful written comments. Thanks also to three anonymous referees and Albert Weale for helping me to improve the argument. The usual disclaimers apply. 
school of thought, loosely inspired by Jürgen Habermas's constitutional patriotism (Verfassungspatriotismus), has argued that patriotic commitment is legitimate in so far as it is directed at universalist-orientated political constitutions and detached from particular cultural contexts. In this article, I assess whether constitutional patriotism succeeds in reconciling democratic legitimacy and cultural diversity. Although I am in broad sympathy with the constitutional patriotic project, I argue that the strategy of the relative insulation of politics from culture that it pursues - at least in its 'neutralist' version - is self-defeating. It turns out to be deficient on the ground of legitimacy - a familiar criticism of constitutional patriotism - but also of inclusiveness - a less common and more damaging criticism. This is because constitutional patriotism fails to take seriously the need for cultural mediations between citizens and their institutions. This need, I suggest, is better accommodated by a more civic form of patriotism, which recognizes the role of particularist political cultures in grounding universalist principles. Civic patriotism is both more 'situated' and more radical than 'neutralist' constitutional patriotism: it emphasizes the motivational prerequisites of democratic governance, stresses the need to preserve existing 'co-operative ventures', and demands that existing political cultures be democratically scrutinized and re-shaped in an inclusive direction. It promotes a mainly political identity, whose political content makes it compatible with a variety of practices and beliefs, but whose thin particularistic form justifies citizens' commitment to specific institutions.

A preliminary observation. Although most normative theories of national identity legitimately claim to be universalizable, they tend to be elaborated in relation to the particular problems faced by particular countries. For example, the differences between David Miller, Yael Tamir, Jürgen Habermas, Dominique Schnapper and Charles Taylor's theories of the nation are best understood as stemming from the diverging experiences of, respectively, Britain, Israel, Germany, France and Canada. Civic patriotism is no different. It is in fact specifically designed for old nation-states characterized by secure boundaries and the co-existence of a dominant historic majority with more recently established immigrant communities. It has comparatively little to say about the more tricky problems arising in immigrant, multinational or deeply divided societies. However, like Habermas's constitutional patriotism, but in less optimistic fashion, it also charts the contours of what would be a legitimate political identity for the citizens of the European polity. The article is structured as follows. The first section shows the limitations of the two dominant interpretations of constitutional patriotism ('critical' and 'neutralist'); the second section highlights the multi-layered nature of national identity; and the next three sections build a case for civic patriotism around three lines of argument: the legitimacy argument, the social-democratic argument and the inclusiveness argument. As will become obvious, but should perhaps be stated at the outset, my revision of constitutional patriotism in a 'civic' direction is primarily motivated by a commitment to a specific set of values, which may broadly be called republican and social-democratic. 


\section{CONSTITUTIONAL PATRIOTISM: CRITICAL AND NEUTRALIST}

The constitutional patriotic account begins with the relatively simple proposition that the relationship between patriotism and cultural diversity is problematic only if, as in nationalist rhetoric, the focus of patriotic loyalty is the dominant culture. If, instead, patriotism is seen as fostering citizens' commitment to the 'abstract procedures and principles" ${ }^{1}$ outlined in the constitution, it becomes compatible with a variety of cultural beliefs and practices. The social bond in a liberal-democratic state should be, in the words of one of Habermas's followers, 'juridical, moral and political, rather than cultural, geographical and historical'. ${ }^{2}$ Allegiance to the political community is thus made independent of individuals' ethnic and cultural origins, religious beliefs and social practices. By thus detaching political loyalty from the dominant culture, constitutional patriotism attractively combines the universalist and inclusive ideals of liberalism with a recognition that citizens of a liberal-democratic polity must display at least some shared dispositions and commitments.

It is, however, the elusive nature of these dispositions and commitments that has attracted the scepticism of critics of constitutional patriotism. Three types of concerns have been raised. First, if universalist inclusiveness requires that constitutional principles be as abstract as possible, how can we justify the requirement that individuals commit themselves to this or that particular constitution or polity $?^{3}$ Secondly, is a commitment to liberal procedures and principles sufficient to actualize the sense of trust and solidarity essential to maintain the thick web of mutual obligations upon which the liberal-democratic state rests? ${ }^{4}$ Thirdly, is it possible to disentangle liberal principles from the particular cultural contexts in which they acquire their practical political significance ${ }^{5}$ Critics of constitutional patriotism have therefore challenged both the feasibility and the desirability of the 'uncoupling' (to use Habermas's term) of political loyalty and cultural affinity. In truth, Habermas himself has been much more aware of these problems, and his constitutional patriotism considerably more subtle than the customary presentation of his views (of which I have given an outline above) suggests. Unfortunately, as I will argue, his followers have tended to develop two alternative interpretations of constitutional patriotism (a 'critical' and a 'neutralist' interpretation) both of which,

\footnotetext{
1 Jürgen Habermas, The New Conservatism: Cultural Criticism and the Historians' Debate (Boston, Mass: MIT, 1989), p. 261.

2 Jean-Marc Ferry, 'Une "philosophie" de la communauté', in J. M. Ferry and Paul Thibaud, Discussion sur l'Europe (Paris: Calmann-Lévy, 1992), p. 174.

${ }^{3}$ For a classic Kantian solution to this problem, see Jeremy Waldron, 'Special Ties and Natural Duties', Philosophy and Public Affairs, 22 (1993), 3-30.

${ }^{4}$ David Miller, On Nationality (Oxford: Clarendon Press, 1995); Margaret Canovan, 'Patriotism is Not Enough', British Journal of Political Science, 30 (2000), 413-32; P. Thibaud, 'L'Europe par les nations (et réciproquement)', in Ferry and Thibaud, Discussion sur l'Europe, pp. 19-126.

5 Veit Bader, 'The Cultural Conditions of Transnational Citizenship: On the Interpenetration of Political and Ethnic Cultures', Political Theory, 25 (1997), 771-813.
} 
in different ways, tend to neglect Habermas's central insight, namely, the role of particularistic political cultures in grounding universalistic principles.

Let me first briefly re-situate constitutional patriotism in the context of Habermas's wider opus. Confronting his conservative opponents in the seminal Historikerstreit (Historians' Debate), Habermas argued that a German liberal democratic national identity could only be elaborated through critical confrontation with the nation's past (in particular the Holocaust). The constitutional patriotism he called for implied, not the denial of the particular historical legacy which the German Republic inherited, but, rather, the adoption of a 'scrutinizing attitude towards one's own identity-forming traditions' by its citizens. ${ }^{6}$ Constitutional patriotism, in his view, involves a selective appropriation of one's past: it demands that political communities come to terms, through remembrance and fortitude, with repugnant legacies, and also that they endorse 'the heritage of cultural traditions that is consonant with [abstract universalist principles]' . Such a 'situated' understanding of constitutional patriotism is in line with Habermas's emphasis on what he calls elsewhere the unavoidable 'permeation of constitutional states by ethics'. 8 Democratic political cultures are grounded in ethical-political communal self-interpretations which reflect the identity of particular political communities. Deliberately-produced law should strive to be "neutral ... vis-à-vis the internal ethical differentiation" ${ }^{\prime 9}$ inherent in multicultural societies, and democratic political cultures should be as far as possible dissociated from the history and culture of the dominant group. However, they will still inevitably express 'an interpretation of constitutional principles from the perspective of the nation's historical experience [which] to this extent, cannot be ethnically neutral'. ${ }^{10}$ This ethical (or cultural) coloration of constitutional principles is not to be lamented. It crucially provides a 'motivational anchorage' for citizens exercising their collective rights of public autonomy, and underpins the development of a 'we-perspective of active self-determination'. ${ }^{11}$ Constitutional patriots, Habermas concludes, must show 'loyalty to the common political culture', not simply to abstract principles. ${ }^{12}$ More recently, he has

${ }^{6}$ Habermas, The New Conservatism, p. 236.

${ }^{7}$ Habermas, The New Conservatism, p. 262.

${ }^{8}$ Habermas, 'Struggles for Recognition in the Democratic Constitutional State', in Amy Gutmann, ed., Multiculturalism (Princeton, NJ: Princeton University Press, 1994), pp. 106-48, at p. 122. By 'ethics', Habermas means the normative dimension of particular cultures and forms of life.

9 Habermas, 'Struggles for Recognition', pp. 134-5.

${ }^{10}$ Habermas, 'Struggles for Recognition', p. 134. On this point, see Shane O'Neil, Impartiality in Context: Grounding Justice in a Pluralist World (New York: State University of New York Press, 1997), esp. chaps 6 and 7; and Thomas McCarthy, 'On Reconciling Cosmopolitan Unity and National Diversity', Public Culture, 11 (1999), 175-208.

${ }^{11}$ Habermas, 'Citizenship and National Identity. Some Reflections on the Future of Europe', in Ronald Beiner, ed., Theorizing Citizenship (New York: State University of New York Press, 1999), pp. 255-68, at p. 263.

${ }^{12}$ Habermas, 'Struggles for Recognition', p. 134. See also Habermas, 'Citizenship and National Identity', p. 278. 
defined constitutional patriotism as a 'patriotism based upon the interpretation of recognized, universalistic constitutional principles within the context of a particular national history and tradition'. ${ }^{13}$ Habermas's constitutional patriotism, therefore, must firmly be situated within the tradition of republican patriotism, for which love of country and love of justice are mutually supportive. ${ }^{14}$ The civic patriotism I defend here elaborates on some central insights of this tradition, too, while taking issue with the interpretation of constitutional patriotism that has become dominant in recent debates about nationalism and liberalism.

Habermasian constitutional patriots have tended to split into two groups - a 'critical' and a 'neutralist' group - both of which have been only selectively faithful to the complexity of the original articulation of Habermas's theory. Critical theorists have concentrated on the radical potential of constitutional patriotism as a subversive force intent on 'de-centring' and destabilizing homogeneous, hegemonic national identities. Drawing on Habermas's defence of 'post-national' identities and on his discursive theory of democracy, they have drawn attention to the pervasive but shifting nature of identities, the unavailability of transcendental, 'neutral' universal principles, the conflictual and open-ended outcomes of struggles for recognition, and the permanent 'failure of equivalence' between principles and institutions. Constitutional patriotism, on their view, should shun all forms of 'identification' and, instead, inform 'practices that resist identification'. Citizens should positively embrace difference, and combat the exclusionary proclivities of appeals to 'closed' (typically national) identities through reflexive, self-critical engagement with others in democratic forums of deliberation. ${ }^{15}$ Critical constitutional patriots are right to point out the subversive impact of constitutional patriotism upon traditional conceptions of national identity, and to suggest that the achievement of genuine inclusiveness requires deliberative democracy. However, because of their sceptical stance towards universal rights and principles, they tend to underestimate their role in constraining agonistic discursive conflicts, whose outcomes may otherwise turn out not to be liberal, inclusive or egalitarian. Further, because of their dismissal of all forms of 'identification' and 'commitment' as potentially oppressive, critical constitutional patriots remain quite elusive about what exactly will motivate citizens actively

${ }^{13}$ Habermas, 'Un débat sur Droit et Démocratie', in Jürgen Habermas, L'intégration républicaine: Essais de théorie politique (Paris: Fayard, 1998), pp. 289-375, at p. 308.

${ }^{14}$ This interpretation of Habermas is notably suggested by Maurizio Viroli, For Love of Country: An Essay on Patriotism and Nationalism (Oxford: Oxford University Press, 1995), pp. 169-77; and J.-W. Müller, Another Country: German Intellectuals, Unification and National Identity (New Haven, Conn.: Yale University Press, 2000), pp. 96-7.

${ }^{15}$ See Patchen Markell, 'Making Affect Safe for Democracy? On "Constitutional Patriotism", Political Theory, 28 (2000), 38-63; Amy Bartholomew, 'Constitutional Patriotism and Social Inclusiveness: Justice for Immigrants?' (paper presented to the Exeter Colloquium on Constitutionalism and Democracy, 2000 (on file with the author)); Gerald Delanty, 'Habermas and Post-National Identity: Theoretical Perspectives on the Conflict in Northern Ireland', Irish Political Studies, 11 (1996), 20-32. 
to engage in the self-critical, other-regarding practice of deliberation in a democratic community. The critical theory of constitutional patriotism, in short, is insufficiently 'constitutional' and insufficiently 'patriotic'. While its advocacy of a deliberative, discursive, potentially radical form of political identity is central to the civic patriotism I articulate below, it cannot stand on its own as a sustained attempt to combine abstract moral universalism with more particular and fairly stable commitments and loyalties.

'Neutralist' constitutional patriots, by contrast, have been more faithful to Habermas's original intentions - the reconciliation of social inclusion and political legitimacy - but, I shall argue at some length in the rest of this article, they have only partially succeeded on both grounds. 'Neutralists' have, unlike critical theorists, neglected the deliberative, critical dimension of constitutional patriotism and, like critical theorists, they have underestimated the role of political culture in underpinning political loyalty and social solidarity. This is because the neutralist version of constitutional patriotism takes Habermas's injunction to 'uncouple' politics and culture (too) literally. For example, for Etienne Tassin, constitutional patriotism 'refuses any convergence between culture and politics' ${ }^{16}$ In most recent discussions, constitutional patriotism is likened to a 'culture-blind' principled patriotism. This tallies with the influential liberal approach to the relationship between citizenship and identity, often interpreted as requiring the state to adopt a 'hands-off' approach in matters of cultural identity: justice requires abstraction from particular bonds and loyalties. ${ }^{17}$ The 'politics/culture' dichotomy is seen as neatly overlapping with germane distinctions central to the liberal articulation of 'thin' principles of the 'right' neutral towards 'thick' conceptions of the 'good'. Constitutional patriotism is thus interpreted as valorizing 'universalism' over 'particularism' ('constitutional patriotism de-ethnicizes citizenship by replacing cultural attachments, which by definition are specific, by allegiance to institutions and symbols which are potentially universalizable' $) ;{ }^{18}$ 'values' over 'identity' ('sharing universal values of democracy and respect for justice and rights [as opposed to sharing an] identity, in the sense of shared language, associations and culture') ${ }^{19}$ and 'procedures' over 'substance' ('constitutional patriotism does not entail loyalty to a specific substantial community, but has the sole

${ }^{16}$ Etienne Tassin, 'Identités nationales et citoyenneté politique', Esprit, 198 (1994), 97-111, p. 111.

${ }^{17}$ For the charge that contemporary liberalism is committed to this misconceived form of cultural neutrality, see Joseph Carens, Culture, Citizenship and Community: A Contextual Exploration of Justice as Evenhandedness (Oxford: Oxford University Press, 2000), pp. 8-14; Will Kymlicka, Multicultural Citizenship: A Liberal Theory of Minority Rights (Oxford: Oxford University Press, 1995), pp. 3-4; Yael Tamir, Liberal Nationalism (Princeton, NJ: Princeton University Press, 1993), pp. $147-50$.

${ }^{18}$ Diane Lamoureux, 'Le Patriotisme constitutionnel et les Etats multinationaux', in François Blais, Guy Laforest and Diane Lamoureux, eds., Libéralismes et nationalismes: Philosophie et politique (Montreal: Presses de l'Université Laval, 1995), pp. 131-44, at p. 132.

19 Attracta Ingram, 'Constitutional Patriotism', Philosophy and Social Criticism, 22 (1996), 1-18, p. 3 . 
meaning of being loyal to the democratic procedures of the constitution'). ${ }^{20}$ In addition, constitutional patriotism is brought to bear on two other important developments within liberal thought: the process of disaggregation of democratic citizenship and legal rights (the latter being increasingly grounded in the universalistic basis of personhood), ${ }^{21}$ and the search for a 'liberal' (that is, non-cultural and universalistic) form of nationalism, of which constitutional patriotism is often presented as the 'purest' version. ${ }^{22}$

This collusion between constitutional patriotism and forms of 'culture-blind' neutralist liberalism, evident in much recent literature, has contributed to obscure the role played by political culture in grounding constitutional patriotism. 'Neutralists', as a result, have not satisfactorily resolved the question of the articulation between universalist principles and particularist cultures. Attracta Ingram, for example, insists that the distinguishing feature of constitutional patriotism is the attempt to substitute 'loyalty to universal values' for 'shared identity'. But she later unexpectedly refers to the need for 'a shared political culture' expressing 'a solidarity rooted in regard for the concrete institutions that belong to our distinct political heritage'. ${ }^{23}$ The problem, of course, is that the very concept of political culture blurs the distinction between (universalist) norms and (particularist) cultures. While implicitly admitting that universalistic principles need to be anchored in particular contexts, neutralist constitutional patriots have been reluctant explicitly to discuss the degree and form of particularistic attachment which could legitimately be fostered, for fear that appeal to particularism was ipso facto a concession to illiberal nationalism. I shall suggest that this need not be the case, and that it is possible to combine the liberal and inclusive insights of constitutional patriotism with an awareness of the role played by political culture in the actual functioning of democratic politics.

\section{LAYERS OF NATIONAL IDENTITY}

Many recent writings on nationalism and patriotism have relied on a well-established distinction between 'civic' (or universalist, or constitutional) nationalism and 'ethnic' (or particularist, or cultural) nationalism, usually to endorse the former and repudiate the latter. Few dichotomies have been more unhelpful than this. Between the so-called 'civic' pole of national identity (which emphasizes shared liberal-democratic values) ${ }^{24}$ and the 'ethnic' pole of

20 Thomas Mertens, 'Cosmopolitanism and Citizenship: Kant against Habermas', European Journal of Philosophy, 4 (1996), 328-47, p. 336.

${ }_{21}$ Yasemin Soysal, Limits of Citizenship: Migrants and Postnational Membership in Europe (Chicago: Chicago University Press, 1994); Jean Cohen, 'Changing Paradigms of Citizenship and the Exclusiveness of the Demos', International Sociology, 14 (1999), 245-68.

${ }^{22}$ For theories of liberal nationalism more partial towards traditional 'cultural' bonds, see Miller, On Nationality; and Tamir, Liberal Nationalism.

${ }^{23}$ Ingram, 'Constitutional Patriotism', pp. 3, 14, 15.

${ }^{24}$ I use 'civic' in a different sense, which is made explicit below. 
national identity (which stresses racial and cultural membership), there is a whole range of intermediate positions which, on reflection, describe the nature of citizens' attachment to their national polity more accurately. National identity is a complex, multi-layered phenomenon, which eludes any simplistic 'either/or' approach. For our purposes here, we can identify at least four layers of identity in a national community. The first is that of ethnic, 'primordial' links based on birth and kinship. The second is that of the broad culture, language, ways of life and social customs characteristic of a particular community. The third is that of the political culture, embodied in political institutions, practices, symbols, ideological and rhetorical traditions, and so forth. The fourth level is that of abstract, universalist political ideals and procedures, usually expressed in the form of general principles outlined in the constitution. Seen in this way, it is obvious that levels two and three of the 'pyramid' of identity may provide a better account of what, in practice, binds people together than either levels one or four, upon which ethnic and civic accounts concentrate exclusively. This, of course, is not to suggest that normative theory should endorse popular understandings of national identity, but it provides a more realistic starting point from which to begin to articulate a viable civic patriotism.

Constitutional patriots have rightly focused on the higher echelons of the 'pyramid' of identity, where the social cement becomes thinner, more political, and therefore more inclusive. As we move up the 'pyramid', essentialist identity (what we are) gives way to voluntarist identification (what we share and do together). The constitutional patriots' intuition is that national identity must be so conceived that it can, as far as possible, become the object of voluntary adhesion from individuals with widely different identities and conceptions of the good. For this to be possible, collective identity must have a primarily political focus. ${ }^{25}$ Constitutional patriots are surely right to exclude the broad culture and ways of life (level two) from their normative definition of national identity. Regardless of whether citizens feel that they do indeed share these things (or even ethnic traits), liberal-democratic governments would be wrong to appeal to and promote them as legitimate bases for social cohesion. This is so for three main reasons: ways of life are too diverse and eclectic to define a common culture; their diffuse character can only with difficulty be the object of voluntary adhesion or democratic scrutiny; and the promotion of a comprehensive common culture of this sort would infringe too much on the liberal values of autonomy and equality.

Neutralist constitutional patriots, as I have argued, are more hesitant regarding the role that political culture (level three) should play in liberal societies. They have fallen short of providing any strong reason to include political culture in the definition of national identity. At bottom, they insist that only abstract political principles and beliefs (level four) are legitimate foci of citizens' attachment to their polity. The civic patriotism I want to articulate here

${ }^{25}$ It would be perhaps more accurate to refer to the collective identity of the polity rather than to an elusive 'national' identity (in this article, I shall use the two indiscriminately). 
endorses their concern to subordinate expressions of particularism to constraining liberal-democratic norms, but does not consider that discarding existing political cultures in favour of universalistic principles is either feasible or desirable. While committed to an essentially political construction of the social bond, civic patriotism acknowledges that the boundaries between the ethnic, cultural and political levels of identity are in practice much more porous than neat analytical distinctions allow. Political institutions and practices cannot be entirely separated from their wider cultural background. Further, liberal democracies need not shed their particular political culture in the name of moral universalism. Citizens can share a commitment to universal principles (civil liberties, equal rights, democratic self-government, etc.) and to the particular institutions and practices which actualize them - if and when they do. In other words, citizens strive to sustain their political culture and institutions because these represent their way of collectively realizing universalist ideals. ${ }^{26}$ This is by no means an intrinsically uncomfortable posture. Civic patriots have always subordinated their allegiance to a country to their love of liberty, even if it is their allegiance to this or that particular polity which coloured their understanding of liberty. ${ }^{27}$ In other words, a patriot should not say 'my country right or wrong', but rather 'my country for the values it represents (or should represent)'. To make my case for civic patriotism, I develop three lines of argument in turn: the legitimacy argument, the social-democratic argument and the inclusiveness argument. In the process, I also ask whether nation-states as they currently exist are the only viable focus of civic patriotism, and I critically discuss a number of influential theories of post-national citizenship (as they are often put forward by neutralist constitutional patriots).

\section{THE LEGITIMACY ARGUMENT}

Picturing what a constitutional patriotic regime would look like requires an effort of imagination, for the simple reason that no existing political regime is based on pure allegiance to abstract principles. The closest approximation to constitutional patriotism comes in the form of a proposal concerning European institutions. For 'post-nationalist' thinkers, the future of Europe lies in a dissociation between political regulation (undertaken at the supra-national level) and cultural identity (cultivated at the national level). European political institutions should draw their legitimacy, not from an elusive European cultural solidarity, but from European citizens' commitment to the broad principles of democracy and human rights. While the post-national European polity should concern itself with the juridical implementation of universalist principles,

\footnotetext{
${ }^{26}$ I owe this formulation to Andy Mason. For his own discussion of patriotic identification, see Andrew Mason, Community, Solidarity and Belonging: Levels of Community and Their Normative Significance (Cambridge: Cambridge University Press, 2000), pp. 115-47.

27 Viroli, For Love of Country; Karma Nabulsi, 'Hope and Heroic Action: Rousseau, Paoli, Kosciuszko, and the Republican Tradition of War', in Nabulsi, Traditions of War (Oxford: Oxford University Press, 1999), pp. 177-240.
} 
nation-states should, for their part, concentrate on the preservation of the 'cultural integrity of national identities'. ${ }^{28}$ This is in many ways an attractive picture, which captures the liberal intuition of the cultural neutrality of democratic politics, whilst being sensitive to feelings of national belonging. However, although the most perspicacious post-nationalists, following Habermas, ${ }^{29}$ advocate the emergence of a 'European public sphere' shaped by a 'shared political culture' and mediating between 'technical' supranational institutions and 'identificatory' national communities, ${ }^{30}$ a radical version of post-nationalism sees the EU as the embryo of a new type of polity based exclusively on 'ethico-political principles', and whose legitimacy 'should in no way pertain to a logic of identity or identification'. ${ }^{31}$ While the nation is the site of 'being' (cultural identity), Europe should become the site of 'doing' (political action).$^{32}$ I want to argue that the risk inherent in such a dissociation of culture and politics is that cultural communitarianisms unchecked by liberaldemocratic norms will stand side by side with universalist institutions devoid of civic-cultural legitimacy. I assess these two dangers in turn.

The first undesirable effect of post-nationalism is the development of ethnic or cultural communitarianisms unregulated by constraining constitutional frameworks. Some post-nationalists mistakenly believe that the separation of culture from politics will lead to the flourishing of non-political, 'private' and therefore (in their view) innocuous forms of cultural expression within the nations and regions of Europe. This misconstrues the nature of identity claims which, qua demands for the public recognition of particular communities, are by definition political. The only interesting question is whether and on which terms such recognition can be made compatible with the moral demands of universalist liberalism. On this view, the best way to defuse the illiberal tendencies of cultural nationalism is not vainly to seek to depoliticize it but, rather, to subject it to liberal-democratic norms. Constitutional frameworks and inclusive democratic deliberation should constrain and regulate what it is permissible to do in the name of a culture. It is therefore illusory to believe that a post-national European state could somehow dispense with intervening in matters of culture. If nothing else, such a state would have to design complex cultural policies and rules with which to adjudicate competing claims for the recognition of national and regional groups, define and guarantee the rights of minorities, choose official languages, and so forth.

At any rate, it is obvious that no easy distinction can be drawn between the domain of 'politics' and the domain of 'culture'. Nor is this to be regretted, for there is a risk involved in the relegation of cultural claims to the fringes of normal politics. If democratic politics fail to take a stand on matters

${ }^{28}$ Ferry, 'Une "philosophie” de la communauté'; p. 194 and passim.

${ }^{29}$ Habermas, 'Citizenship and National Identity'; 'L'Europe a-t-elle besoin d'une constitution?' in Habermas, L'intégration républicaine, pp. 151-7.

${ }^{30}$ Ferry, 'Une "philosophie” de la communauté', pp. 141, 147, 188, 197.

${ }^{31}$ Tassin, 'Identités nationales et citoyenneté politique', p. 108.

32 Tassin, 'Identités nationales et citoyenneté politique', p. 106. 
of cultural identity, these might end up being monopolized by anti-democratic movements, as in the case of the French rightist National Front. ${ }^{33}$ Democratic politics should not shy away from seeking to harness to its own norms the inevitable expression of identity claims. Instead of a disorientating pretence of cultural neutrality (as abstention), liberal-democratic states would be well advised to promote a thin, civic understanding of communal membership (of which I give an outline below). This, it should be noted, is not simply a prudential move, which acknowledges the pervasiveness of sentiments of cultural belonging and attempts to 'civilize' them. It is also a principled move, which recognizes that democratic politics can also be 'civilized' and legitimized by feelings of cultural identification.

This is because the second undesirable effect of post-nationalism is the emergence of supranational institutions devoid of popular support - a worrying prospect for those concerned with political legitimacy and participation. Supranational institutions which cannot evoke the trust of their constituent communities will find it difficult to pursue long-term collective goals in other than coercive fashion. Post-nationalism tends to underestimate the motivational conditions of democratic governance, the most important of which being the continued identification of citizens with their institutions. The development of institutions lacking in civic-cultural significance is likely to aggravate the chief symptoms of democratic malaise, namely, cynicism towards democratic rule, reluctance to share the burden of social justice, resentment towards aloof and acculturated elites, decline of civic dispositions, alienation vis-à-vis an increasingly 'privatized' public sphere. To be fully legitimate, political institutions must be perceived by citizens as democratic forums of self-rule, where debate is inclusive and comprehensible, representatives fully accountable, and decisions publicly justified. A well-functioning public sphere of this sort would seem to require something more than a shared commitment to universal principles, something which motivates citizens to feel that particular institutions are somehow theirs, in a meaningful sense, so that they are in a position to adopt what Habermas calls the 'we-perspective of active selfdetermination'. ${ }^{34}$ It is this concern for democratic legitimacy that has led a prominent Habermasian post-nationalist, Jean-Marc Ferry, progressively to elaborate a more 'civic' (in the sense used here) interpretation of European constitutional patriotism. He now suggests that for citizens to feel 'integrated in the "we" of political culture', a European 'culture of citizenship' must be fostered, which requires the 'communisation' of national political cultures in a trans-European public sphere and their critical confrontation through deliberative practices. European patriotism, on this view, is no longer simply about assent to fundamental juridical and procedural principles: it signifies a willingness critically and publicly to reflect on the ethical components of the historical identities of 'Europe'. Only then could a 'shared democratic culture

${ }^{33}$ See, e.g., Pierre-André Taguieff, with Philippe Petit, La République menacée (Paris: Textuel, 1996); Yves Lacoste, Vive la nation: Destin d'une idée géopolitique (Paris: Fayard, 1997).

${ }^{34}$ Habermas, 'Citizenship and National Identity', p. 263. 
in a post-national Europe', based on the ethics of discussion, emerge. ${ }^{35}$ Undoubtedly, a deliberative democratic culture of this sort is a more stringent prerequisite for European citizenship than mere assent to constitutional principles and, to that extent, it might take some time for the European polity to duplicate the motivational conditions of democracy. ${ }^{36}$

But the general point is clear enough: for democracy to be effective, universalist principles must be woven into the fabric of local conversations in ways that resonate with the political self-understanding of the society in question. Post-nationalism tends to underestimate the level of indeterminacy of liberal-democratic ideals and the way in which they need to be articulated, interpreted, implemented and contested within particular political contexts to be culturally significant and politically effective. General principles such as equality of opportunity or free speech, for example, do not carry much weight until they are brought in as guiding ideals in deliberations about particular public issues, and applied interpretively in the light of all the information relevant to the concrete context. Further, democratic values must be entrenched in law but also in mores, so that they come to embody a core of communal selfrepresentations. This is important because liberal societies are no less concerned than illiberal societies with defining who they are, and being seen to live up to their self-image.

In May 1999, a number of public figures condemned a racially-motivated bomb attack in Brixton (London) as a vicious attack on values held dear by British society: diversity, toleration, non-violence and the like. No one, I take it, understood them to mean that such 'British' values thereby lacked universal validity. Rather, the point was to remind a particular community of its own public commitments to universal values, and warn of its failure to live up to them. The suggestion that the principles of national identity were betrayed by such a gross violation of human rights correctly implied that there was a particular kind of shame attached to the infringement of cherished values by one's co-citizens. Such feelings of shame (and pride) for the actions of one's co-citizens are an important incentive for political mobilization, and would be incomprehensible if politics had simply an instrumental and not an identificatory function. Nor is identification unconditionally owed to existing institutions. The prior commitment of civic patriots to the ('level four') values of liberty and democracy is bound to enhance their sense of 'democratic indignation' (to use Habermas's term $)^{37}$ at the failings of their own government, and their

35 Jean-Marc Ferry, La Question de l'Etat européen (Paris: Gallimard, 2000), pp. 72-85, 161-9. For his earlier formulations, see 'Identité et citoyenneté européenne: A propos du sommet de Maastricht', in Jacques Lenoble and Nicole Dewandre, eds., L'Europe au soir du siècle: Identité et démocratie (Paris: Esprit, 1992), pp. 177-88; 'Une "philosophie" de la communauté,, 'Pertinence du postnational', Esprit, 176 (1992), pp. 80-93.

${ }^{36}$ For a slightly different criticism of European constitutional patriotism, see Rainer Bauböck, 'Citizenship and National Identities in the European Union', Harvard Working Papers, 4 (1997), $13-17$.

37 Jürgen Habermas, 'The Second Life Fiction of the Federal Republic: We Have Become Normal Again', New Left Review, 197 (1993), 58-66. 
willingness to act upon it. Such an active, freedom-loving citizenry must be educated in the habits of democratic self-government, and civic education will play a crucial role in this process. The legitimacy and stability of liberaldemocratic institutions depends on it, as does their permanent correction and improvement through citizens' mobilization.

\section{THE SOCIAL-DEMOCRATIC ARGUMENT}

I have argued that post-nationalism - and, by implication, neutralist constitutional patriotism - underestimates the identificatory nature of (even liberal) politics, but have left unresolved the most difficult question, namely, are nation-states therefore the primary locus for vibrant social-democratic politics? A number of authors have argued that cultural affinity is essential to social solidarity. More specifically, they point out that national identity is uniquely conducive to trust, mutual commitment, fellow-feeling and a capacity to compromise with and make sacrifices for others. These virtues are particularly crucial in underpinning schemes of social justice and the extensive redistribution of wealth that they demand. David Miller in Britain and Paul Thibaud in France are the most articulate exponents of this social-democratic argument for patriotism. ${ }^{38}$

Although such a line of argument is likely to be intuitively appealing to republicans and socialists concerned with the preservation of social-democratic practices in a globalized world, I would not want to endorse it in its strong version. While it may be that nation-states are de facto the most significant loci of social solidarity, it does not follow that national belonging is of intrinsic ethical significance, let alone that the obligations it entails should override duties of global justice. ${ }^{39}$ There seems to be no necessary connection between national fellow-feeling and solidaristic attachments: what matters, more than a sense of nationality per se, is the right kind of public spirit and social ethos. ${ }^{40}$ The version of the social-democratic argument for patriotism that I want to propose makes more limited claims. In so far as global justice is (regrettably) little more than a distant possibility, and in so far as the only vibrant cosmopolitanism today is that of the free market, there is a case for the defence of local schemes of social justice. Therefore, I shall suggest that the civic patriotic position does not rule

38 Thibaud, 'L'Europe par les nations', pp. 61-2; Miller, On Nationality. See also Brian Barry, 'Self-Government Revisited', in David Miller and Larry Siedentop, eds, The Nature of Political Theory (Oxford: Oxford University Press, 1983), pp. 121-54; Charles Taylor, 'Why Democracy Needs Patriotism', in Martha C. Nussbaum, ed., For Love of Country: Debating the Limits of Patriotism (Boston, Mass: Beacon Press, 1996), pp. 119-21.

${ }^{39}$ Miller makes a (nuanced) case to that effect in 'National Self-Determination and Global Justice', in his Citizenship and National Identity (Cambridge: Polity Press, 2000), pp. 161-79.

${ }^{40}$ Wayne Norman, 'Les points faibles du modèle nationaliste libéral', in Blais, Laforest and Lamoureux, Libéralismes et nationalismes, pp. 83-5; Bhikhu Parekh, 'The Incoherence of Nationalism', in Beiner, Theorizing Nationalism, pp. 313-16; Andrew Mason, 'The State, National Identity and Distributive Justice', New Community, 21 (1995), 241-54. 
out (indeed favours) the extension of solidaristic attachments beyond nationstates - in Europe and elsewhere - but is, as a matter of priority, concerned about their sheer survival in an increasingly globalized world.

On balance, economic globalization seems to have had a corrosive impact on the conditions of social democracy. The requirements of global financial discipline have tended severely to constrain the scope for progressive policies and to undermine the social bargain on which the post-Second World War welfare state rested, notably by undermining the power of states to reach democratic consensus on the redistribution of wealth and power. ${ }^{41}$ Although republican democracy would be, in an ideal world, best realized through international schemes of social justice and transnational forums of democracy, in today's world, the preservation of valuable social-democratic practices might well be conditional on the upholding of existing, national schemes of solidarity. Progressive thought is likely to reconsider its disdain for nation-states if the latter prove to be the only effective bulwark against the 'negative cosmopolitanism ${ }^{42}$ that induces the decline of democracy solidarity, the erosion of social rights, the decay of public services and the widening of inequalities, notably through what has been called the 'secession of the rich'. ${ }^{43}$ Until it can be demonstrated that globalization can be complemented by a concomitant internationalization of social justice, there is a prima facie presumption in favour of a weak, 'conditional' version of the Miller-Thibaud thesis.

This goes something like this. Ceteris paribus - that is, given the current paucity of evidence today that vibrant social-democratic practices can be global - it would be foolish to discard existing democratic foundations, namely, state-level 'co-operative ventures'. The intuition is mainly prudential: as long as market-driven globalization is unable to reproduce the motivational and cultural conditions which have historically underpinned democracy and social solidarity, social democrats have no interest in dismantling existing networks of solidarity. This is not incompatible with their commitment to set up transnational forums of democracy and to create the conditions for the emergence of new public spheres wherever possible - democratizing existing supranational institutions, strengthening cosmopolitan law, improving global wealth redistribution, fostering transnational and grassroots participation and

${ }^{41}$ G. Garret and P. Lange, 'Political Responses to Interdependence: What's "Left" for the Left?' International Organization, 45 (1991); Tariq Banuri and Juliet B. Schor, eds, Financial Openness and National Autonomy (Oxford: Oxford University Press, 1992); John Gray, After Social Democracy (London: Demos, 1996); Robert Cox, 'Democracy in Hard Times: Economic Globalization and the Limits to Liberal Democracy', in Anthony McGrew, ed., The Transformation of Democracy? Globalization and Territorial Democracy (Cambridge: Polity Press, 1997), pp. 49-71. For alternative views, see the discussion and bibliography in David Held, Anthony McGrew, David Goldblatt and Jonathan Perraton, Global Transformations: Politics, Economics and Culture (Cambridge: Polity, 1999), pp. 13-14 and passim.

${ }^{42}$ Richard Falk, 'Revisioning Cosmopolitanism', in Nussbaum, For Love of Country, pp. 53-60.

43 Robert Reich, cited in Lacoste, Vive la nation, p. 300. 
the development of trust and familiarity between citizens of different countries, so as to encourage the emergence of a "cosmopolitan democracy" ${ }^{44}$ able to reproduce the vitality of traditional patriotism. Of course, for reasons suggested in the previous section, national citizenship, in so far as it is a more effective channel for the cultivation of a 'we-perspective of active self-determination', should not be supplanted by transnational citizenship: the two should, rather, operate at different levels and in relation to different areas of common interest. The main point here is that, on the civic patriotic account, there is little reason to think that national citizenship and transnational citizenship are undercutting one another. ${ }^{45}$ On the contrary, a well-understood patriotism and a generous cosmopolitanism are mutually supportive.

This is because civic patriots are committed, not to the intrinsic value of a particular national tradition, nor to abstract, towering universalism, but to the dissemination of good democratic practice at all levels, and to a socially progressive 'dialogic universalism'. ${ }^{46}$ Because of the civic patriots' central commitment to social justice, they will fight against the hegemony of a thin, minimalist understanding of cosmopolitanism (that of civil rights and the free market) on two fronts: by promoting a basic human right to subsistence ${ }^{47}$ and international economic co-operation, and by defending the right of democratic communities to endorse more expansive interpretations of the requirements of social justice. ${ }^{48}$ Nor, again, are these two objectives necessarily in tension with one another. It is surely no coincidence that countries with a strong social-democratic tradition - such as Scandinavian countries and, to some extent, Canada - are also those which make the most extensive contributions to global wealth redistribution. A patriotism which nurtures both mutual concern and a non-particularistic ethos is likely to be a more effective school of cosmopolitan citizenship than a disembodied universalism, and the civic

${ }^{44}$ David Held, 'Democracy: From City-States to a Cosmopolitan Order?' Political Studies, 40 (1992), Special Issue, 10-39.

45 As claimed by David Miller, 'Bounded Citizenship', in Kimberly Hutchings and Roland Dannreuther, eds, Cosmopolitan Citizenship (Basingstoke, Hants: Macmillan, 1999), pp. 60-80.

${ }^{46}$ Andrew Linklater, The Transformation of Political Community: Ethical Foundations of the Post-Westphalian Era (Columbia: University of South Carolina Press, 1998), chap. 3. This on my view is slightly different from Michael Walzer's 'reiterative universalism' which is illustrated by him with the example of the Italian patriot Mazzini: 'like the man who wanted to dance at every wedding, Mazzini was eager to endorse every reiteration of Italy's national struggle' (Michael Walzer, 'Nation and Universe', in Grethe B. Peterson, ed., The Tanner Lectures on Human Values XI (Salt Lake City: University of Utah Press, 1990), p. 550. Dialogical universalism is concerned not only with the dissemination of good democratic practices but also with the possibility of transnational democratic communication and co-operation.

${ }^{47}$ For a defence, see, e.g., Charles Jones, Global Justice: Defending Cosmopolitanism (Oxford: Oxford University Press, 1999).

${ }^{48}$ I agree with Jo Carens's general statement that 'what justice requires or permits is contextually specific in some respects - dependent on the history and culture(s) of a political particular community - but generalizable in other respects, in the form of principles that are morally binding upon all states' (in Culture, Citizenship and Community, p. 16). See also his section in the same volume on 'Justice as Concentric Circles', pp. 32-6. 
virtues cultivated in this way can best sustain transnational citizenship. Put differently, the moral significance of universalist principles is likely to be grasped more fully when they are entrenched within particular political cultures. In this sense, it is true, as Miller points out, that cosmopolitan democracy is likely to be parasitical on practices of citizenship nurtured in smaller, often national communities. ${ }^{49}$ But, I would contend, the opposite is also true, that good citizenship at home can be enhanced by exposure to foreign, trans- or supranational experiences. Such experiences are in fact crucial in fostering a disposition central to civic patriotism, namely, the willingness critically to scrutinize one's own institutions and practices by appealing to universally justifiable ('level four') standards. One rationale for this concern is that the promotion of national identity should not, on the civic patriotic account, take place at the cost of democratic inclusiveness.

\section{THE INCLUSIVENESS ARGUMENT}

I have argued that in contrast to neutralist constitutional patriotism, civic patriotism is not a priori hostile to the forging of links between national fellow-feeling and the pursuit of ideals of social justice and democracy. However, in so far as patriotic sentiment can only be instrumental to the achievement of wider goals, it will have to be of a certain kind and of a certain intensity. Not every patriotism will do - not only will it have to be social-democratic in inclination, but also it will have to be inclusive. The issue of inclusiveness is all the more salient since liberal-democratic societies are increasingly multicultural in character and, pace neutralist constitutional patriotism, their dominant sense of 'national identity' is as much coloured by the particular history and culture of the historic majority as by citizens' attachment to universalist values. So instead of seeking to provide considerations about the value of national identity considered abstractly, civic patriotism aims to scrutinize existing nationalist practices and alter them in relation to whether they further, or else impede, the realization of liberal and democratic goals. The fact that civic patriotism is more pragmatic than neutralist constitutional patriotism, therefore, does not mean it is less demanding in terms of the demands if makes of the majority culture. As Will Kymlicka has noted, the attitude of 'benign neglect' in matters of culture is detrimental to a critique of the implications, notably for members of minority cultures, of the imbrication or overlap between the majority culture and state politics. ${ }^{50}$ Before giving more substance to the concept of an inclusive political culture, I now want to suggest that a civic patriotic strategy, by taking seriously the 'banal nationalism' which permeates our societies, would involve a significant 'cleaning up' of existing public spheres in an inclusive direction. I argue that the democratic ethos of civic patriotism makes it more receptive to issues of cultural exclusion than neutralist constitutional patriotism. It is at this juncture that the insights of 'critical'

${ }^{49}$ Miller, 'Bounded Citizenship', p. 77.

${ }^{50}$ Kymlicka, Multicultural Citizenship, pp. 3-4. 
constitutional patriotism (developed in the first section of the argument) are most useful.

'Banal nationalism' has been coined to refer to the continual 'flagging', or reminding, of nationhood, which is so discreet that it is to be found in the embodied habits of social life, in the daily rhetoric of the 'we' evinced, for example, in the coverage of sporting events or in the national weather forecast. ${ }^{51}$ I use it slightly more restrictively, to refer to the often invisible cultural coloration of seemingly universalist institutions, laws, practices and rhetoric. No public sphere of existing liberal democratic states can be culturally neutral. It inevitably expresses a particularistic heritage made up of complex ideological traditions, established languages, national symbols, frequent references to a shared - if often mythical - history, particular ways to structure time and space, accepted styles of argument and rhetorical devices, and so forth. Even so-called civic nations, such as the United States and France, have anchored their liberal principles to a particularist legacy. ${ }^{52}$

Civic patriotism takes as its starting point this fact of the non-neutrality of the public sphere. It recognizes that most liberal-democratic political cultures reflect the norms, history, habits and prejudices of majority groups. Yet although it does not believe that banal nationalism per se is illegitimate or illiberal, it is highly sensitive to the ways in which certain expressions of banal nationalism alienate cultural minorities. There are two main justifications for this particular civic patriotic concern. On the one hand, in contrast to neutralist constitutional patriots, civic patriots take seriously the importance of cultural mediations between citizens and their institutions, and the identificatory role of the latter. On this view, only those democratic institutions will be legitimate which can effectively secure the loyalty of all citizens (including members of cultural minorities). On the other hand, in contrast to nationalists, civic patriots believe that the value of national identity primarily lies in its contribution to sustaining feelings of solidarity between all citizens. So the conflation of 'national' identity with the historic majority's culture cannot be justified on civic patriotic grounds. Rather, expressions of banal nationalism in the public sphere which are found to be offensive or alienating to certain groups in society will have to be challenged. In this respect, civic patriotism takes the existing imbrication of politics and culture seriously and urges a considerable 'thinning out' of national cultures. In relation to the actual practice of liberal democracies, civic patriotism is both more realistic and more demanding than neutralist constitutional patriotism because, firstly, it does not ignore the fact that all liberal public spheres are inevitably particularistic and, secondly, it requires a selective examination of expressions of seemingly 'banal' nationalism.

Let me take an example, which illustrates the difference between the civic patriotic 'principled realism' and the attitude of 'benign neglect'. There is an oft-noted gap between abstract 'culture-blind' theories of citizenship and

${ }^{51}$ See Michael Billig, Banal Nationalism (London: Sage, 1997).

${ }^{52}$ This point is forcibly made by Bader, 'Cultural Conditions', pp. 774-80. 
the actual practice of states concerning the requirements of citizenship. Despite all liberal democracies' commitment to the ideal of universalist, voluntarist membership, few have actually pressed the principle so far as to make citizenship conditional on the mere holding of liberal democratic values by individuals. ${ }^{53}$ This is most obvious for citizens born in the country, who may turn out to embrace fascist values without thereupon losing their status of citizens. But it also applies to newcomers, who may be expected to demonstrate some political loyalty, but are for the most part subjected to requirements of socialization, albeit at a minimal level (a certain duration of residence and proficiency in the official language are the most common conditions for the acquisition of citizenship). Paradoxically, therefore, liberal citizenship is founded less on voluntarist identification with abstract values than on a requirement of familiarity with a country's culture and institutions.

The problem is that this requirement of socialization or familiarity, not being articulated and justified publicly, knows no clear, agreed-upon boundary. A possible consequence is that newcomers (and their descendants) are likely to be confronted with confusing and often excessive expectations on the part of members of the majority. Tariq Modood makes the point well:

Clarity about what makes us willingly bound into a single country relieves the pressure on minorities, especially new minorities whose presence within the country is not fully accepted, to have to conform in all areas of social life, or in arbitrarily chosen areas, in order to rebut the charge of disloyalty. [Absence of clarity] allows politicians unsympathetic to minorities to demand that they demonstrate loyalty by doing $\mathrm{x}$ or $\mathrm{y}$ or $\mathrm{z}$, like supporting the national cricket team in Norman Tebbit's famous example. ${ }^{54}$

There is a case, therefore, for a publicly defined and more focused definition of citizenship requirements than the current reliance on the amorphous criterion of minimum socialization. Civic patriots, in contrast to neutralist constitutional patriots, argue that it would be futile to pretend that we can dispense with socialization in favour of abstract shared values. In contrast to nationalists, however, they insist that it is crucially important that the character, purpose and limits of socialization be precisely specified. Civic patriots argue that no more can be asked of newcomers than that they become familiar with the country's political culture in such a way as to become 'functioning' citizens.

It is now time to clarify this concept of political culture, a task which I have left to the very end, although I have throughout hinted at its contours. The dilemma with which we are faced is this: while the shared values promoted by neutralist constitutional patriotism might be too 'thin' a foundation for social

53 This is the most common criticism levelled at advocates of a 'voluntaristic' definition of citizenship. See, e.g., Bernard Yack, 'The Myth of the Civic Nation', in Beiner, Theorizing Nationalism, pp. 103-18.

54 Tariq Modood, 'Establishment, Multiculturalism and British Citizenship', Political Quarterly, 65 (1994), 64-5. See also Miller, On Nationality, p. 137. 
democracy, the shared collective identity defended by nationalists will be too 'thick' to be able to accommodate minority groups. The nationalist strategy is, from a civic patriotic point of view, not only morally objectionable but also tactically self-defeating. To the extent that the active promotion of the majority's culture aggravates the alienation of cultural minorities, it falls short of the ideal of inclusiveness, regardless of the benefits it might otherwise bring (such as an enhanced sense of collective identity for the majority). Is there a path between the Scylla of thick collective identity and the Charybdis of thin shared values? I believe that there is, and that a strong political culture can provide a solid but inclusive basis for democratic legitimacy. Civic patriotism seeks to promote a mainly political identity, whose predominantly political nature makes it compatible with a variety of practices and beliefs, but whose thin particularistic content justifies citizens' commitment to specific institutions and practices.

Political culture can be defined as the loose and malleable framework which sustains our political conversations over time. It includes familiarity with collective institutions, political rituals and rhetoric, types of discourses, and accumulated habits and expectations stemming from previous conversations. This does not assume substantial agreement. In fact, as Jeremy Webber has argued, societies that have the clearest national character are defined less by their agreements than by the distinctive structure of their fundamental debates and disagreements. We value our country because we value the particular character of its public debate. ${ }^{55}$ The character of public debate is itself not a fixed, unchanging property of the conduct of politics in a particular polity, but rather an artificial construct constantly altered by the emergence of new groups and new claims. The political culture of every democratic society bears the marks of the particular struggles of historically excluded groups - workers, the poor, women, immigrants - seeking to appropriate the existing public sphere and make good its abstract democratic promises of emancipation and equality. Even acute class conflicts have been shaped by, and have in turn shaped, national political cultures. Excluded groups have used the radical resources provided by democratic ideals to challenge systematic patterns of exclusion and impose a more expansive, more universalist form of communal self-understanding. They have done so by integrating, and then often subverting, existing particularist institutional and ideological structures.

So structures evolve, if only incrementally, as new voices are heard and new issues come to the fore. Witness the ways in which, in most countries, public discourse has accommodated environmental or feminist rhetoric without thereby losing its distinctive national character. It is true that sometimes, structures are judged altogether too outdated or objectionable to be upheld. Even when they are abruptly dispensed with, however, efforts are invariably made to resume some sort of continuity, so that the change is not so incomprehensible as to bear no referent in the public culture in question. Even

55 Jeremy Webber, Re-Imagining Canada: Culture, Community and the Canadian Constitution (Kingston \& Montreal: McGill-Queen's University Press, 1994), pp. 186-92. 
cases of radical re-invention, such as the German ideal of constitutional patriotism, make sense within a particular tradition of public debate, in which, for example, critical reflection on a collective past looms large (as suggested above) and for which the 'we' (in this case the citizens of the post-1990 united Germany) is not in question. In other words, even the apparent repudiation of particularism by constitutional patriots (be they German, French or American) does not appear in a historical vacuum but, rather, takes place within a recognizably particularist framework of political meaning. Civic patriotism takes seriously the importance of this framework of political meaning - a synonym of political culture - in providing the broad contours of communal self-interpretation. But it also insists that the political culture itself be one of the objects of democratic deliberation. Existing ethnic and civic practices should be scrutinized, and only those which secure the reasoned acceptance of all those affected by it should be upheld. What is likely to happen is that mainly 'thin' political elements will pass the test of deliberation, but it cannot be excluded that a variety of 'ethnic' practices will be maintained, because they are deemed innocuous (e.g., most street names), convenient (e.g., Christian calendar), or open to re-interpretation and deconstruction (e.g., aspects of national history).

Civic patriotism, as a result, does not require that minority groups simply conform to the dominant culture provided their basic rights are respected. It demands more, namely, that they feel 'at home' with what must be a genuinely shared national identity. This puts pressure on the majority group, urging it to open up the public sphere, to allow widespread contestation of deeply entrenched practices and beliefs, and to trim down its public culture. Of course, while every claim will be listened to, not all claims will be accepted. Rather, all groups can expect to have their demands publicly scrutinized and democratically discussed, so as to favour the emergence of a shared 'framework of political meaning'. ${ }^{56}$ The concept of 'framework of political meaning' may appear at once too vague and too strong. It may be too vague if it lacks any clear focus that could make it the object of voluntary identification, and it may be too strong if it refers to a historically transmitted, comprehensive set of habits and dispositions that only members of the majority culture are likely to master. In both cases, it may be doubted that political culture is as inclusive as I have suggested it can be. Although the force of the objection is undeniable, I think it misses central characteristics of political culture. Political culture is different from the wider culture (which, to recall, includes the 'level two' broad culture, language, ways of life and social customs characteristic of a community) in a number of crucial ways. As Bhikhu Parekh puts it, in contrast to the wider culture, which is diffuse, has weak enforcement mechanisms and an eclectic character, 'political identity has an objective point of reference in the community's legal and political institutions, is a subject of constant public

${ }^{56}$ For a sensitive exploration of examples of democratic cross-cultural deliberation, see Bhikhu Parekh, Rethinking Multiculturalism: Cultural Diversity and Political Theory (Basingstoke, Hants: Macmillan, 2000). 
discussions and attentions, is preserved in the recorded memory of the community and is therefore comparatively easy to elucidate and maintain' ${ }^{57}$ Political culture is therefore more focused and more institutional than the wider culture and, more importantly, it has an artificial character: it is created and altered by political activity itself. The only thing that can be required of citizens is that they be willing to engage in the conversation, that they see it as their own, and that they learn the skills which allow them to participate in it.

Two final considerations suggest that civic patriots will expect that the public culture be re-shaped to reflect some of the concerns of minority groups. On the one hand, a strong, republican concept of political equality ('the requirement that all individuals and groups have access to the political process' $)^{58}$ ensures that inclusiveness is built into the civic patriotic model. It is a condition of the legitimacy of political institutions that all can be listened to, and can identify with the decisions reached on the basis of inclusive deliberation. On the other hand, in a deliberative democracy, non-political identities are not a priori excluded from the public sphere. This ensures that the public culture itself will be an object of democratic deliberation between majority and minority groups. Civic patriotism believes in the broad malleability of culture and repudiates any essentialist conception of national identity. It takes seriously the importance of invented traditions, imagined histories and founding myths, as flexible cultural artefacts constituting common (or at least overlapping) worlds of meaning. So, while requiring that all citizens be socialized into the same political culture, it does not take this culture as a fixed legacy but as a 'lived' experience. Civic patriotism, in short, urges us collectively to engage in the ongoing project of the universalization of our political culture.

\section{CONCLUSION}

Let me recall the questions I began by asking. What kind of cultural affinity is required for political loyalty? How much does it take for distant people to 'feel politically responsible for each other', in Habermas's phrase ? ${ }^{59}$ If we care, as I think we should, about the intensity of political deliberation, the survival of social-democratic practices, and the combined pursuit of legitimacy and inclusiveness, what kind of patriotism do we need? I have argued that constitutional patriotism underestimates (and sometimes misunderstands) the role of particularist political cultures in grounding universalistic principles of democracy and justice. Civic patriotism, by contrast, emphasizes the motivational conditions of democratic governance, stresses the need to preserve

\footnotetext{
${ }^{57}$ Bhikhu Parekh, 'The Concept of National Identity', New Community, 21 (1995), 255-68, p. 260.

${ }^{58}$ Cass R. Sunstein, 'Beyond the Republican Revival', Yale Law Journal, 97 (1988), 1539-694, p. 1552 .

59 Jürgen Habermas, 'The European Nation-State - its Achievements and its Limits', in Gopal Balakrishnan, ed., Mapping the Nation (London: Verso, 1996), pp. 281-94, p. 286.
} 
existing co-operative ventures such as nation-states, and urges that existing political cultures be democratically scrutinized and re-shaped in an inclusive direction. It promotes a mainly political identity, whose political content makes it compatible with a variety of practices and beliefs, but whose thin particularistic form justifies citizens' commitment to specific institutions and practices. This commitment is not so unconditional as to justify blind loyalty to one's own institutions, nor is it so absolute as to rule out forms of cosmopolitan citizenship. 